\title{
Evaluation of a virtual learning environment about educational actions for people with diabetes mellitus
}

\author{
Avaliação de um ambiente virtual de aprendizagem sobre ações educativas para pessoas com \\ diabetes mellitus
}

Evaluación de un entorno virtual de aprendizaje sobre las acciones educativas para personas con diabetes mellitus

Camila Aparecida Pinheiro Landim Almeida ${ }^{1}$ Kayo Henrique Jardel Feitosa Sousa ${ }^{2}$ Joseane Lima de Oliveira ${ }^{1}$ Luana da Silva Lima ${ }^{1}$ Tiara Soares Santos ${ }^{1}$ Fernanda Cláudia Miranda Amorim ${ }^{1}$ Cláudia Maria Sousa de Carvalho ${ }^{1}$ Adélia Dalva da Silva Oliveira ${ }^{1}$ Herica Emilia Félix de Carvalho ${ }^{3}$ Bruna Sabrina de Almeida Sousa ${ }^{4}$

1. Centro Universitário UNINOVAFAPI. Teresina, PI, Brasil.

2. Universidade Federal do Rio de Janeiro, Escola de Enfermagem Anna Nery. Rio de Janeiro, RJ, Brasil.

3. Universidade de São Paulo, Escola de Enfermagem de Ribeirão Preto. Ribeirão Preto, SP, Brasil.

4. Universidade Federal do Piauí. Teresina, PI, Brasil.
Corresponding author:

Kayo Henrique Jardel Feitosa Sousa

E-mail: kayohenriquejardel@hotmail.com

Submitted on 02/05/2019.

Accepted on 07/10/2019.

DOI: 10.1590/2177-9465-EAN-2019-0027

\section{Abstract}

Objective: To evaluate, from the perspective of Nursing students, a virtual learning environment about educational actions for people with diabetes mellitus. Method: A cross-sectional and descriptive study with qualitative data analysis and a sample of 71 nursing students. A questionnaire was used to collect data that includes pedagogical and theoretical aspects of the virtual learning environment: content, interaction, activities, response time and interface quality. Results: The results showed that there was a good evaluation of the parameters in most of the evaluated items, except for the figures and sound of the VLE interface domain, which evaluates the quality of the platform design. Conclusion and implications for practice: In the students' evaluation, the virtual learning environment was a potential tool for the technical and complementary development of nursing, in addition the inclusion in the virtual world of learning.

Keywords: Educational Technology; Staff Development; Students, Nursing; Health Education; Diabetes Mellitus.

\section{REsUMO}

Objetivo: Avaliar, na perspectiva de estudantes de Enfermagem, um ambiente virtual de aprendizagem sobre ações educativas para pessoas com diabetes mellitus. Método: Estudo transversal e descritivo, realizado com 71 estudantes de Enfermagem. A coleta de dados foi realizada por meio de um questionário que contempla aspectos pedagógicos e teóricos do ambiente virtual de aprendizagem: conteúdo, interação, atividades, tempo de resposta e qualidade da interface. Resultados: Os resultados demonstraram que houve boa avaliação dos parâmetros na maioria dos itens avaliados, exceto os itens figuras e som do domínio interface do AVA, que avalia a qualidade do design da plataforma. Conclusão e implicações para a prática: Na avaliação dos estudantes, o ambiente virtual de aprendizagem apresentou-se como uma ferramenta em potencial para o desenvolvimento técnico e complementar de Enfermagem, além da inclusão no mundo virtual de aprendizagem.

Palavras-chave: Tecnologia Educacional; Desenvolvimento de Pessoal; Estudantes de Enfermagem; Educação em Saúde; Diabetes Mellitus.

\section{REsumen}

Objetivo: Evaluar, en la perspectiva de estudiantes de Enfermería, un ambiente virtual de aprendizaje sobre las acciones educativas para personas con diabetes mellitus. Método: Estudio transversal y descriptivo con análisis cualitativo de datos y con muestra de 71 estudiantes de enfermería. Para la recolección de datos, se utilizó una encuesta que contempla aspectos pedagógicos y teóricos del ambiente virtual de aprendizaje: contenido, interacción, actividades, tiempo de respuesta y calidad de la interfaz. Resultados: Los resultados demostraron que hubo una buena evaluación de los parámetros en la mayoría de los ítems evaluados, excepto los ítems figuras y sonido del dominio interfaz del AVA, que evalúa la calidad del diseño de la plataforma. Conclusión e implicaciones para la práctica: En la evaluación de los estudiantes, el ambiente virtual de aprendizaje se presentó como una herramienta potencial para el desarrollo técnico y complementario de la enfermería, además de la inclusión en el mundo virtual de aprendizaje.

Palabras clave: Tecnología Educacional; Desarrollo de Personal; Estudiantes de Enfermería; Educación en Salud; Diabetes Mellitus. 


\section{INTRODUCTION}

In order to face the difficulties and reach a better quality in higher education, offering online teaching-learning tools throughout the academic training represents a promising pedagogical strategy for undergraduate courses in the healthcare field, especially when related to the importance of professionals in the practice of health education in chronic conditions.

An example of a chronic health condition is Diabetes Mellitus (DM), which is characterized by producing insufficient insulin or not absorbing it properly, detected by high sugar levels in blood, in other words, hyperglycemia. This condition affects body metabolism, causes damage to tissues and organs and may result in the development of acute and chronic complications in the short- and long-term.1-2

The Brazilian Diabetes Society ${ }^{3}$ has shown that the world population with DM was in the range of 387 million in 2014 and it is estimated to reach 471 million in 2035. The International Diabetes Federation ${ }^{1}$ reported that there will be 642 million people with DM all over the world in 2040. The growth in prevalence and incidence of DM, premature mortality and the costs involved in controlling and treating the complications have revealed this chronic condition as a severe public health issue, especially when it is close to alarming epidemic proportions..$^{4-6}$

The person diagnosed with DM needs a multidisciplinary follow-up of a team that will provide support to live with this disease. In Brazilian public health system, the multidisciplinary team consists of a doctor, a nurse, a dental surgeon, a nurse technician, an oral health technician and a community health agent, forming the Family Health Care team (FHCt). In this team, each member has specific and common assignments in the follow-up of the person with DM. ${ }^{7}$

It is essential to provide conditions for people with DM to develop autonomy about their own healthcare, such as selfmanagement. In this perspective, health education is pointed out as the most effective way to reach this purpose. ${ }^{8}$ In health practices and policies, health education has been based on health promotion assumptions, focused on preventing diseases through direct interaction between health professionals and the population. ${ }^{9}$

Consequently, in the field of developing human resources in healthcare, especially of nurses as active agents of promoting health in life with chronic conditions, the concern of higher education institutions (HEls) with providing qualified professionals to the market arises and must be overcome by improving the process of nursing students. In the online education field and in front of several advances in Information and Communication Technologies (ICTs), it is essential to evaluate digital technologies in higher education learning, from the perspective of a Nursing student. ${ }^{10-11}$

In Nursing undergraduate courses, the teaching-learning process has been subjected to questions about searching strategies, resources and ICTs applied in training nurses with a critical and reflexive profile. ${ }^{12}$
In the teacher's perception, there are three big difficulties in using ICTs. The first one is related to the lack of infrastructure; the second, to the lack of specific training in the field; and the third, to the lack of incentives to change educational conceptions and practices. ${ }^{13}$ While in a graduating student's perception, there is lack of deepening in diverse teaching strategies, of didactic resources and of the use of digital tools, which could be employed with the aim of providing a bigger teacher-student interaction in classroom and virtual learning environments. ${ }^{14}$

Given the difficulties presented in the literature, the need and relevance of evaluating the ICTs used in the formation of nurses is evident in order to contribute with diminishing these gaps. ${ }^{13-14}$ The research proposal aims to evaluate, from Nursing students' perspectives, a virtual learning environment about educational actions for people with diabetes mellitus. This evaluation compiles both teachers' and students' characteristics, interaction between them, content transmission and interface used.

The contribution of the study is based on providing information of social and scientific relevance. Social relevance, when considering the graduating student as an essential part in the construction of its own formation; and scientific relevance is related to the knowledge production about a topic of current interest, which is the use of virtual environments in a nurse formation process. The results of the current study may contribute to the fomentation of ICTs' use according to technological development in undergraduate teaching.

\section{METHOD}

It is a cross-sectional and descriptive study developed in a private University Center in the city of Teresina, Piauí, Brazil, in the period September-November 2017.

The University Center has an online platform, the Virtual Learning Environment (VLE). The VLE is a virtual classroom used for two purposes: remote teaching formation consistent with the quality standards determined by the Ministry of Education, offering the following undergraduate courses: Business Administration, Human Resources and Social Services; and for complementary formation in other undergraduate courses, for example, the Bachelor's degree in Nursing. This complementary formation refers to the incorporation of subjects totally or partially developed in the VLE.

The population universe was constituted by all the 363 students properly enrolled in the Bachelor's degree in Nursing in the University Center chosen as the place of study. The inclusion criteria were: being a student in the said course, properly enrolled between the $2^{\text {nd }}$ and $9^{\text {th }}$ periods, agreeing with the proposed activities plan and fulfillment of the total course workload. Excluded: students in medical leave during the course offering and/or data collection.

Simple random-type sampling with reposition was used, with an error margin below $5 \%$ and a $95 \%$ confidence level. In that way, the calculated sample quantity was 187 students. From those, after fulfilling the inclusion and exclusion criterion established for the study, 129 students were enrolled in Curso de Educação em Saúde no Diabetes Mellitus (Educational Course 
in Diabetes Mellitus Heath). However, 33 did not complete the minimum hour load for conclusion during the proposed period, 16 did not complete all the mandatory activities and nine never accessed the Course. Consequently, from the initial total, 71 Nursing students completed the course.

The study was developed by means of composing three phases: analysis and design, development and evaluation of the VLE by the students. ${ }^{15}$ The analysis and design phase consisted in the exact search of the real necessity for the demand of teaching strategies that justified the indispensable quality of the course proposal, as well as the use of a VLE. In that phase, diverse elements like objectives, contents, target audience, study environment and technological infrastructure were analyzed. To that end, an activity plan was made, which took the following into consideration: identification data (course, target audience, theme, responsible professor, post-graduate students, tutors, hour load and period), objectives (both general and specific), menu, schedule and references.

The development phase included the materialization of the media used in the VLE and their availability to the students. According to the schedule described in the activity part, they were developed in four modules: (1) Basic principles, evaluation, diagnosis, complications and diseases related to DM; (2) DM treatment and complications; (3) Health education in the perspective of the person with DM; and (4) Health education for DM in the view of health professionals working in Family Health Strategy (FHS) (Estratégia Saúde da Família, ESF). Each module considered a 20 hour load. 10 hours relating to case report discussion by means of chats were added in the last week of each module's end. In that way, the activities included in the VLE considered a 90 total hour load.

The human resources for content preparation and for the application of the VLE's activities were the following: two female doctors in Nursing, one Master's in Nursing, two Master's female students, a number of Information Technology (IT) professionals related to the Remote Education Nuclei of the University Center, scientific initiation scholarship students and other students who collaborated with the HEls.

With the materialization of the design prepared in the first phase, the available activities in the VLE had Health Education about Diabetes Mellitus as their theme. With regard to the language used in the tools (texts, forums and chats), the following prerogatives' were prioritized: simplicity, clarity and objectivity, so that the programmatic contents became more accessible to Nursing students.

After finishing the proposed activities by the VLE, data collection was started in VLE's evaluation, third phase. For the VLE's evaluation by the Nursing students, an instrument adapted from a proposal that presents questions relating to pedagogical aspects was used..$^{16}$ That proposal was also used in a research which pretended to describe the evaluation by Nursing graduates of a VLE for teaching Endocrine Physiology in a Nursing Bachelor's Course of a public university in the inland of the State of São Paulo. ${ }^{17}$
The instrument used in this study is an adapted version for Nursing students which contemplates the following pedagogical aspects: content, interaction and activities, and technical aspects related to the response time and to the interface quality. ${ }^{17}$

The features evaluated in each of these items were the following: content (relevance, clarity, applicability, quantity and consistency), interaction in the VLE (student-student, student-VLE, student-group, student-tutor and group-tutor); course's activities (relevance, clarity, applicability, quantity, educational consistency and evaluation), VLE's interface quality (accessibility, ease of navigation, colors, figures, and sound). For each of these items, the participants attributed a value, namely: $(+1)$ meant that the feature was totally met; $(0)$ the feature was partially met; and $(-1)$ the feature was not met. When they selected the values of $(0)$ and $(-1)$, participants included comments/explanations.

Data was organized in a Microsoft Excel program spreadsheet, by means of double-typing and subsequent validation, and exported to the Statistical Package for the Social Sciences (SPSS) software, version 22.0. For the quantitative data, descriptive statistics were used: numerical $(\mathrm{n})$ and percentage (\%) proportions.

In the case of the comments and explanations analyses, when the participants' selection were (0) and (-1), content analysis of the phrases collected in the data collection instrument was used according to the operational proposal. ${ }^{18}$ Initially, an exploratory analysis of the researched group's characteristics was done, followed by the interpretative phase, which made it possible to gather the following registration units: clarity, interaction, activity overload, design and accessibility.

In developing this research as a whole, ethical premises were followed, according to Resolution No. 466/2012 of the National Health Council (Conselho Nacional de Saúde, CNS), with the approval of the University Center's Ethics Committee in Research, under Opinion No. 2,064,751.

\section{RESULTS}

Of the course's final 71 Nursing students, $88.7 \%$ were female, $70.4 \%$ belonged to the age group of 18 to 26 years old, $45.1 \%$ were born in the city of Teresina/PI and $87.1 \%$ were single. With respect to the academic characteristics, $22.5 \%$ of the students was in the $6^{\text {th }}$ period, followed by $7^{\text {th }}$ and $8^{\text {th }}$ ( $14.1 \%$ each), $64.8 \%$ lived with their families and $60.6 \%$ spent up to 20 minutes to get to the HEls.

The Nursing students submit the evaluation of the items related to the content, to the interaction in the VLE, to the course's activities and to the VLE's interface in Table 1.

The results found in Table 1 show that there was a good parameter evaluation in the majority of the evaluated items, save from those of figures and sound belonging to the VLE's interface, which evaluate the design quality of the platform, being evaluated as not met characteristics by more than half of the people who ended the course.

Data extracted from the responses/comments to the items partially met and not met were grouped in the following registration units: 
Table 1. Responses gathered in the Nursing students' evaluation on the content, interaction, course activities and VLE interface, according to the fulfillment of the following characteristics: pertinence, clarity, applicability, quantity and consistency. Teresina, PI, Brazil, 2017.

\begin{tabular}{|c|c|c|c|c|c|c|c|c|}
\hline \multirow{2}{*}{ Characteristics } & \multicolumn{2}{|c|}{ Met } & \multicolumn{2}{|c|}{ Partially met } & \multicolumn{2}{|c|}{ Not met } & \multicolumn{2}{|c|}{ Total } \\
\hline & $\mathrm{n}$ & $\%$ & $\mathrm{n}$ & $\%$ & $\mathrm{n}$ & $\%$ & $\mathrm{n}$ & $\%$ \\
\hline \multicolumn{9}{|l|}{ Content } \\
\hline Pertinence & 70 & 98.59 & 01 & 1.41 & - & - & 71 & 100 \\
\hline Clarity & 70 & 98.59 & 01 & 1.41 & - & - & 71 & 100 \\
\hline Applicability & 70 & 98.59 & 01 & 1.41 & - & - & 71 & 100 \\
\hline Quantity & 70 & 98.59 & 01 & 1.41 & - & - & 71 & 100 \\
\hline Consistency & 70 & 98.59 & 01 & 1.41 & - & - & 71 & 100 \\
\hline \multicolumn{9}{|l|}{ Interaction in the VLE } \\
\hline Student-Student & 67 & 94.37 & 04 & 5.63 & - & - & 71 & 100 \\
\hline Student-VLE & 69 & 97.18 & 02 & 2.82 & - & - & 71 & 100 \\
\hline Student-Group & 57 & 80.28 & 12 & 16.90 & 02 & 2.82 & 71 & 100 \\
\hline Student-Tutor & 63 & 88.73 & 07 & 9.86 & 01 & 1.41 & 71 & 100 \\
\hline Group-Tutor & 62 & 87.32 & 08 & 11.27 & 01 & 1.41 & 71 & 100 \\
\hline \multicolumn{9}{|l|}{ Course activities } \\
\hline Pertinence & 71 & 100.00 & - & - & - & - & 71 & 100 \\
\hline Clarity & 68 & 95.77 & 02 & 2.82 & 01 & 1.41 & 71 & 100 \\
\hline Applicability & 70 & 98.59 & 01 & 1.41 & - & - & 71 & 100 \\
\hline Quantity & 68 & 95.77 & 01 & 1.41 & 02 & 2.82 & 71 & 100 \\
\hline Educational evaluation & 71 & 100.00 & - & - & - & - & 71 & 100 \\
\hline \multicolumn{9}{|l|}{ VLE's interface } \\
\hline Accessibility & 66 & 92.96 & 04 & 5.63 & 01 & 1.41 & 71 & 100 \\
\hline Ease of navigation & 71 & 100.00 & - & - & - & - & 71 & 100 \\
\hline Colors & 66 & 92.96 & - & - & 05 & 7.04 & 71 & 100 \\
\hline Figures & 24 & 33.80 & - & - & 47 & 66.20 & 71 & 100 \\
\hline Sound & 13 & 18.31 & - & - & 58 & 81.69 & 71 & 100 \\
\hline
\end{tabular}

clarity (the content was found in summarized way, was scarcely comprehensible and limited); interaction (need for participants' simultaneity for a more deeper debate in the forums and chats and distancing from the tutors); activity overload (time limit not compatible with the need for rationalization for carrying out the activities); and design and accessibility (fairly compelling cores and Internet quality access).

\section{DISCUSSION}

The study's results highlight the prevalence of the female gender among the Nursing students, which denotes preliminary characteristics on certain aspects of the Nursing graduation profile, already noted in the literature. ${ }^{19}$
There was also predominance of Nursing students in the young age group, data corroborated by a study carried out with university Nursing students who assisted to a public university in the inland of Piauí. ${ }^{20}$ The majority of students mentioned they came from Teresina/PI, contrary to the findings of another research carried out in Montes Claros/MG, where students, in their majority, were born and lived in the city were they study. ${ }^{21}$

In this study, the majority of the students were single, similarly to what happened in a study with the Nursing course of a federal university situated in the Northeast of Brazil, of which more than $90 \%$ mentioned they were single. ${ }^{22}$

As regards the academic characteristics, it was observed in this study that the majority of the students were enrolled in the last school semesters, the period of academic to working life transition, together with a task increase with a high level of 
demand and responsibilities, which can generate tensions and anxieties. $^{23}$

In relation to the people with whom the students lived, the majority said they lived with their families. The beneficial condition is highlighted since family absence, or little family living in the same household, can contribute to the student getting some disease, and becoming more susceptible to emotional disorders. ${ }^{24}$

Those socio-demographic data are important for discussion in the sense that they reveal a public which can master the digital media, which would ease the development and handling of the platform developed for the course.

ICTs stimulate big transformations in countless knowledge areas. The area of education emerges as one of those which showed the biggest growth with an impact in the teaching-learning process, new opportunities and even challenges for teachers and students. Practicing challenging activities, task follow-up carried out by students with evaluative feedbacks and the adequate use of technological digital resources are but some of the teaching strategies which motivate university students to search for knowledge. ${ }^{25-26}$ That ICTs' evolution favored a revolution in Remote Education (Educação a Distância, EaD).

$\mathrm{EaD}$ brought about new possibilities for the processes related to teaching and, mainly, to learning, since it allows reaching a higher number of students, by means of access in diverse places, only with a minimum of available technology and time for learning. ${ }^{27}$

Regarding some ICT's educational materials, the VLEs stand out for being widely used in the national and international higher education of Nursing. They are part of diverse tools and functionalities that help the teaching-learning process in a dynamic and interactive perspective, using synchronous and asynchronous tools, such as forums, questionnaires, video-lessons, and chats, with flexibility in time management and space of learning, evaluation tools, and the didactic process control..$^{28}$

Interactive tools such as forums, chats, e-mails, and others are usually available in VLE platforms, since they are organized spaces for didactic-pedagogical purposes that, combined with the teachers' and tutors' work, have contributed to a more interactive format in remote education. ${ }^{29-30}$

The online course of this study on Health Education in Diabetes Mellitus was developed with four modules, text and article reading and interpretation, resolution of case studies, chats, forums, wherein the participants were assisted by teachers and tutors responsible for the course's organization and for monitoring in the institutional VLE. In general, the Nursing students evaluated that the features were met; however, less than two percent indicated that these features were partially met.

In this study, the evaluation's results allow deducing that the students showed a considerable level of satisfaction with this educational tool, similarly to what was found in another study ${ }^{31}$. The virtual environment presents itself as a pleasant tool, complementary to the classes, stimulating economy and interest in the content, showing motivation for the use the educational tools. ${ }^{31}$

There are still difficulties in identifying and using these strategies, even in teaching environments considered as familiar, because it is still an initial experience of the student in this educational context when compared to the experience in traditional classroom teaching. ${ }^{26}$ This is confirmed from a study ${ }^{31}$ that shows how the Nursing students evaluated a virtual learning tool for the teaching of peripheral venous vascular semiology, where $85 \%$ reported not having difficulty during navigation in the virtual learning tool; however, $15 \%$ indicated such difficulty. Another study reinforces the necessity for using more images and clearer writing for better understanding the content. ${ }^{17}$

The content of the course, organized in modules intending to ease students' understanding, was considered summarized by five participants, who also reported difficulties to understand it. Evaluating the content features of a VLE, professional Nursing profession students disagreed about the logical organization, clarity, and conciseness of the content. ${ }^{32}$ This fact may be related to the inability to locate the desired information due to not being acquainted with the study method or the manipulation of the tools of the course, requiring prior preparation. ${ }^{33}$

It is important to highlight that the VLE is not intended to teach, but rather to create learning conditions. It is not only a passive mediator, but an instrument for the active dialogue between an individual and his/her environment. ${ }^{34-35}$ Thus, it is essential to strengthen the need to revise platforms' structure to turn them into a modern technology, easily comprehensible as well as to provide additional readings for deepening knowledge and immersion in the thematic work.

According to this perspective, it is worth to mention the Technology Information Guiding Education Reform (TIGER) initiative, which was developed by nurses and computer professionals of the United States of America (USA). To sum up, TIGER developed a VLE that empowers nurses in the use of computing to provide safe and high quality care based on seven pillars, namely: Communication and collaboration; Teaching; Computer Design; Information Technology; Culture; Management; and Leadership and Policies. ${ }^{36}$

The initiative described above suggests an environment beyond institutional structures and demonstrates how the ICTs are being disseminated around the globe. The objective of this initiative is to instruct care professionals and Nursing academics on computer skills, from elementary to advanced level Information Technologies (IT) skills with the main focus on high-tech care for patients. ${ }^{37}$

Regarding the interactions in chats and according to the course participants, the results were quite relevant and satisfactory, even when four students mentioned that student-student interaction in VLE should be more clear. A study carried out with Nursing students in Pernambuco showed a weighted average of 0.91 for the information exchange item with colleagues and professors. ${ }^{11}$

Thus, rhythm, constancy of interaction and feedback between student-tutor, group-tutor and also encouragement with positive and altruistic messages are fundamental to create commitment to the educational process. ${ }^{27}$ Interaction in a VLE is essential to shorten geographical and physical barriers, therefore, chat rooms can be used as online meeting spaces. ${ }^{17}$

So, it is advisable to have students at the same time in chat rooms to solve case studies and to increase the interaction of 
tutors in these environments, which denotes the importance of simple manipulation of the synchronous and asynchronous communication tools of the course, thus allowing interaction among students, contents and tutors. To supply for this demand, it is recommended to use forums, in other words, an asynchronous communication tool used to share discussions of the topics proposed by professors and tutors, not necessarily occurring at the same time. . $^{27,30}$

With respect to the interaction, one study ${ }^{38}$ demonstrated that the ways for interaction and support among those individuals involved in the online educational environment are extremely valuable. The leading role of the tutor in the platform, especially by promoting unique relationships among human beings, such as motivation and encouragement for students to participate in the activities and also to offer improvements in the reflective process through sharing experiences was pointed out. Thus, merely providing didactic material does not guarantee effectiveness in the teaching-learning process.

It becomes relevant to note that Nursing training recognizes the Internet as a strong working tool. VLEs and the online complementary trainings augment the impact of information transmission in large amounts of time and long-distance contact. ${ }^{29}$

Activities applicability responded to the students' expectations; however, there was a warning on the part of the participants to the case studies applied which demanded little reasoning. In another study, ${ }_{11}^{1}$ students classified the "time management" and "self-discipline" items as moderately adequate for online teaching.

It is pertinent to state that, in the VLE, the student needs to develop search skills and skills to deepen their knowledge, they have to learn how to learn and commit to the proposed activities. To that end, the students' profile must be considered and, in the case of this study, the students in different graduation stages in Nursing, which can be used as a justification to the warning about the simplicity of the case studies.

In that situation, online teaching strategies offer students autonomy in the search and construction of their own knowledge, since they have to think critically and acquire the necessary skills for that during that teaching strategy, which requires great reasoning. ${ }^{11,33}$

In this sense, basically two trends about the use of the ICTs in education are highlighted: instructionism and constructionism. The first trend privileges information's presentation to the student or as instruction-type interactions, that is, the student answers the proposed questions either having a qualified response or not. The second trend provides experimentation by the student, simulation, playing and constructing based on a compatible environment with such actions and in a context that is qualified for that. ${ }^{34}$

With regard to the quantity of proposed activities, it was aligned with the satisfaction of the majority of students, and only one of them stated there should be fewer activities or more time to complete them. Such circumstance can be related to inadequate time management due to the great task volume. Time management difficulties may bring about resistance and bad results in learning. ${ }^{11,39}$ The use of VLEs lets users develop self-management competencies, with a professor acting as mediator in this process.

With regard to the VLE interface, features were met in a positive manner, in the students' perspective. Despite this, initial access problems and access difficulty associated to Internet quality were mentioned. This situation corroborates studies that mention adaptation to a new learning environment as a necessary skill for accessing the virtual medium and for learning in it, and that some students did not have Internet in their homes and had little time to study in the Higher Educations Institutions (HEls)' computers, a fact that may have limited access to the VLE. ${ }^{29,40}$

The VLE interface design must be enjoyable and attractive to "catch" student attention, since some of them made comments related to the colors of the VLE, for being the same as the institutional ones, with the recommendation of brighter colors.

For websites' improving, design updating, change of color pattern and used fonts and improvement of distribution of icons that could confuse user's browsing are needed. The lack of illustrative images in some contents can make the identification of some relevant information hard as well. Thus, it is recommended to use bright colors, readable fonts, images and illustrations that can offer a more dynamic, interactive and enjoyable teachinglearning process. . $7,29,40^{2}$

The study had showed, as a limitation, the number of participants being lower than previously established, as a result of the delay weeks for course beginning, which could have reduced the time of familiarization and adaptation of the Nursing students to the VLE and justified the reduced number of participants that completed the activities in the course's platform. The identification of that limitation can be relevant so that such an unexpected event be the mainstream of planning at future virtual practices.

The other limitation of the study is related to the method, that didn't assessed the knowledge acquired by the students after the course, since the intention was to verify the quality of the tool. Therefore, for subsequent studies, it is recommended to use the evaluation of the knowledge acquired by means of pre- and post-tests to the course members, in addition of the evaluation of the tool.

Despite the methodological limitations, this study brought contributions as health education in DM is an important nurse's action in the scenario of Primary Health Care, thus, it is necessary to innovate on the teaching of that theme. Therefore, the use of ICTs must be a reality and encouraged in education. HEls must use ICTs on curricular matrix during academic formation in health courses, making it necessary that IT teachers and professionals be qualified and motivated for acting on this tool.

\section{CONCLUSION AND IMPLICATIONS FOR PRACTICE}

In the Nursing students' evaluation, the VLE was showed as a satisfactory tool, since the searched qualities on that platform had its features achieved in percentages that are higher than 
$50 \%$ each item, excepting image items and the sound of VLE's interface field. It is reiterated that data related to the "sound" item is not applied as activities that have that attribute were not done. Therefore, the four course modules, reading and interpretation of texts and articles, case study, chats and forums were considered as satisfactory during the process.

Comments of the features partially met and not met referred to the need for a betterVLE organization regarding the synchronization of established deadlines and planned activities, institutional accessibility, more support from engaged tutors and teachers and previous training for the VLEs' ease of navigation.

The outcomes of this study show many implications for Nursing, mainly for the educational practice. The course Education in Health on Diabetes Mellitus supported the professional formation process by promoting motivational learning by means of multimedia resources. The course is equal to a complementary didactic resource for theoretical teaching in Nursing undergaduate courses.

\section{REFERENCES}

1. International Diabetes Federation. Atlas do Diabetes 2015: atualização. $8^{\text {th }}$ ed. [Internet]. 2017 [cited 2018 Apr 11]. Available from: http://www. diabetesatlas.org/

2. American Diabetes Association. Classification and Diagnosis of Diabetes. Diabetes Care [Internet]. 2017 Jan; [cited 2018 Apr 11]; 40(Suppl 1):S11-24. Available from: http://dx.doi.org/10.2337/ dc17-S005

3. Sociedade Brasileira de Diabetes. Diretrizes da Sociedade Brasileira de Diabetes 2014-2015. São Paulo: SBD;2016. Available from: https://www. diabetes.org.br/publico/images/2015/area-restrita/diretrizes-sbd-2015. pdf

4. Ríos EV, Anaya RP, Daza ERV, González LM, Rodríguez LG. Costo por estadio de la atención integral del paciente diabético tipo 2 con enfermedad renal crónica. Physis [Internet]. 2017 Oct/Dec; [cited 2018 Dec 26]; 27(4):1125-46. Available from: http://dx.doi.org/10.1590/S010373312017000400014

5. Freitas GA, Souza MCC, Lima RC. Prevalência de diabetes mellitus e fatores associados em mulheres indígenas do Município de Dourados, Mato Grosso do Sul, Brasil. Cad Saúde Pública [Internet]. 2016 Sep; [cited 2018 Apr 11]; 32(8):e00023915. Available from: http://dx.doi. org/10.1590/0102-311X00023915

6. Freitas RWJF. Diabetes Mellitus: a serious public health problem. Rev Enferm UFPI [Internet]. 2016 Oct/Dec; [cited 2018 Apr 11]; 4(4):1-3. Available from: http://www.ojs.ufpi.br/index.php/reufpi/article/view/5003/ pdf

7. Ministério da Saúde (BR). Portaria № 2.488, de 21 de outubro de 2011. Aprova a Política Nacional de Atenção Básica, estabelecendo a revisão de diretrizes e normas para a organização da Atenção Básica, para a Estratégia Saúde da Família (ESF) e o Programa de Agentes Comunitários de Saúde (PACS). Brasília (DF): Ministério da Saúde; 2011.

8. Mendonça FF, Nunes EFPA. Avaliação de grupos de educação em saúde para pessoas com doenças crônicas. Trab Educ Saúde [Internet]. 2015 May/Aug; [cited 2018 Apr 11]; 13(2):397-409. Available from: http:// dx.doi.org/10.1590/1981-7746-sip00053

9. Salci MA, Meirelles BHS, Silva DMGV. Health education to prevent chronic diabetes mellitus complications in primary care. Esc Anna Nery [Internet]. 2018 Jan; [cited 2018 Apr 11]; 22(1):e220170262. Available from: http://dx.doi.org/10.1590/2177-9465-ean-2017-0262

10. Avelino CCV, Borges FR, Inagaki CM, Nery MA, Goyatá SLT. Development of a course in the Virtual Learning Environment on the ICNP®. Acta Paul Enferm [Internet]. 2016 Jan/Feb; [cited 2018 Dec
26]; 29(1):69-76. Available from: http://dx.doi.org/10.1590/1982 0194201600010

11. Holanda VR, Pinheiro AKB, Holanda ER, Santos MCL. Teaching and learning in a virtual environment: nursing students' attitude. REME Rev Min Enferm [Internet]. 2015 Jan/Mar; [cited 2018 Apr 11]; 19(1):148-53. Available from: http://dx.doi.org/10.5935/1415-2762.20150012

12. Grossi LM, Pisa IT, Marin HF. Information and Communication Technology in Nursing Audi. J Health Inform [Internet]. 2015 Jan/Mar [cited 2019 Mar 30]; 7(1):30-4. Available from: http://www.jhi-sbis.saude. ws/ojs-jhi/index.php/jhi-sbis/article/view/314/227

13. Albinio R, Souza CA. Evaluation of the communication and information technology usage in Brazilian schools: an exploratory data analysis of the technology for education Brazilian report. E\&G Econ Gest (Belo Horizonte) [Internet]. 2016 Apr/Jun; [cited 2019 Mar 30]; 16(43):101-25. Available from: http://periodicos.pucminas.br/index.php/economiaegestao/\%20 article/view/P.1984-6606.2016v16n43p101/9930

14. Chavaglia SRR, Barbosa MH, Santos AS, Duarte RD, Contim D, Ohl RIB. Estratégias didáticas identificadas junto a graduandos de enfermagem. Cogitare Enferm [Internet]. 2018; [cited 2019 Mar 30]; 23(3):e53876. Available from: http://dx.doi.org/10.5380/ce.v23i3.53876

15. Mendoza PB, Galvis AP. Ambientes virtuales de aprendizaje: uma metodología para su creación. Inform Educ [Internet]. 1999; [cited 2018 Apr 11]; 12(2):295-317. Available from: http://avabenm2014.ucoz. com/_ld/0/10_APA6.pdf

16. Zem-Mascarenhas $\mathrm{SH}$, Cassiani SHB. A criança e o medicamento: software educacional sobre administração de medicamentos em pediatria. Rev Bras Enferm [Internet]. 2000 Oct/Dec; [cited 2019 Jun 2]; 53(4):499-507. Available from: http://dx.doi.org/10.1590/S003471672000000400003

17. Rangel EML, Mendes IAC, Cárnio EC, Alves LMM, Crispim JA, Mazzo A, et al. Evaluation by nursing students in virtual learning environments for teaching endocrine physiology. Acta Paul Enferm [Internet]. 2011; [cited 2018 Apr 11]; 24(3):327-33. Available from: http://dx.doi.org/10.1590/ S0103-21002011000300004

18. Minayo MCS. O desafio do conhecimento: pesquisa qualitativa em saúde. São Paulo: Hucitec; 2014.

19. Araujo MAN, Lunardi Filho WD, Leite LRC, Ma RTK, Silva AA, Souza JC. Nursing students' quality of life. Rev Rene [Internet]. 2014 Nov/ Dec; [cited 2018 Apr 11]; 15(6):990-7. Available from: http://dx.doi. org/10.15253/2175-6783.2014000600012

20. Avelino CCV, Costa LCS, Buchhorn SMM, Nogueira DA, Goyatá SLT. Teaching-learning evaluation on the ICNP® using virtual learning environment. Rev Bras Enferm [Internet]. 2017 May//Jun; [cited 2018 Dec 26]; 70(3):602-9. Available from: http://dx.doi.org/10.1590/00347167-2016-0545

21. Lima CA, Vieira MA, Costa FM. Caracterização dos estudantes do curso de graduação em Enfermagem de uma universidade pública. Rev Norte Min Enferm [Internet]. 2014; [cited 2018 Apr 11]; 3(2):33-46 Available from: http://www.renome.unimontes.br/index.php/renome/ article/view/72/

22. Bernardino AO, Coriolano-Marinus MWL, Santos AHS, Linhares FMP Cavalcanti AMTS, Lima LS. Motivation of nursing students and their influence in the teaching-learning process. Texto Contexto Enferm [Internet]. 2018 Mar; [cited 2018 Apr 11]; 27(1):e1900016. Available from: http://dx.doi.org/10.1590/0104-070720180001900016

23. Moreira DP, Furegato ARF. Stress and depression among students of the last semester in two nursing courses. Rev Lat Am Enferm [Internet] 2013 Jan/Feb; [cited 2018 Apr 11]; 21 (no.spe):155-62. Available from: http://dx.doi.org/10.1590/S0104-11692013000700020

24. Costa MAR, Oliveira JLC, Souza VS, Inoue KC, Reis GAX, Matsuda LM. Associação entre estresse e variáveis sociodemográficas em estudantes de enfermagem de uma instituição do Paraná. Rev Enferm UFJF [Internet]. 2016; [cited 2018 Apr 11]; 2(1):9-19. Available from: https://periodicos.ufjf.br/index.php/enfermagem/article/view/3837

25. Costa CPV, Luz MHBA. Digital learning object for diagnostic reasoning in nursing applied to the integumentary system. Rev Gaúcha Enferm [Internet]. 2015 Oct/Dec; [cited 2018 Apr 11]; 36(4):55-62. Available from: http://dx.doi.org/10.1590/1983-1447.2015.04.54128 
26. Beluce AC, Oliveira KL. Scale of strategies and motivation for learning in virtual environments. Rev Bras Educ [Internet]. $2016 \mathrm{Jul} / \mathrm{Sep}$; [cited 2018 Apr 11];21(66):593-610. Available from: http://dx.doi.org/10.1590/ S1413-24782016216631

27. Alves VLS, Okagawa FS, Parra JFG, Bohomol E, Cunha ICKO. Virtual interactivity: web forum café in a nursing management course. REME Rev Min Enferm [Internet]. 2015 Jan/Mar; [cited 2018 Apr 11] 19(1):134-40. Available from: http://www.dx.doi.org/10.5935/14152762.20150011

28. Salvador PTCO, Bezerril MS, Mariz CMS, Fernandes MID, Martins JCA, Santos VEP. Virtual learning object and environment: a concept analysis. Rev Bras Enferm [Internet]. 2017 May/Jul; [cited 2018 Dec 25]; 70(3):572-9. Available from: http://dx.doi.org/10.1590/0034-71672016-0123

29. Mori S, Whitaker IY, Marin HF. Evaluation of an educational website on First Aid. Rev Esc Enferm USP [Internet]. 2013 Aug; [cited 2018 Apr 11]; 47(4):950-7. Available from: http://dx.doi.org/10.1590/S0080623420130000400025

30. Souza GC, Gonçalves MNC, Martins MMFPS, Borges EMN, Mira VL, Leite MMJ. Evaluation of the online management course from the perspective of former students. Rev Esc Enferm USP [Internet]. 2015 Dec; [cited 2018 Apr 11]; 49(no.spe2):90-7. Available from: http://dx.doi. org/10.1590/S0080-623420150000800013

31. Gadioli B, Fulquini FL, Kusumota L, Gimenes FRE, Carvalho EC. Construction and validation of a virtual learning object for the teaching of peripheral venous vascular semiology. Esc Anna Nery [Internet] 2018 Aug; [cited 2018 Dec 25]; 22(4):e20180043. Available from: http:// dx.doi.org/10.1590/2177-9465-EAN-2018-0043

32. Góes FSN, Camargo RAA, Fonseca LMM, Oliveira GF, Hara CYN, Felipe HR, et al. Avaliação de tecnologia digital educacional "sinais vitais e anatomia" por estudantes da educação profissionalizante em enfermagem. Rev Min Enferm [Internet]. 2015 Apr/Jun; [cited 2019 May 29]; 19(2):44-50. Available from: http://www.dx.doi.org/10.5935/14152762.20150024

33. Gharib M, Zolfaghari M, Mojtahedzadeh R, Mohammadi A, Gharib A. Promotion of critical thinking in e-learning: a qualitative study on the experiences of instructors and students. Adv Ave Educ Pract [Internet] 2016 May; [cited 2018 Apr 11]; 7:271-9. Available from: https://www. ncbi.nlm.nih.gov/pmc/articles/PMC4862758/
34. Cristovão HM, Nobre IA. Software educativo e objetivos de aprendizagem. In: Nobre IA, Nunes VB, Gava TBS, Fávero RP, Bazet LMB, orgs. Informática na educação: um caminho de possibilidades e desafios. Serra: Instituto Federal de Educação, Ciência e Tecnologia do Espírito Santo;2011.p. 127-59. Available from: http://educimat.ifes. edu.br/images/stories/Publica\%C3\%A7\%C3\%B5es/Livros/Livro-PIECaminhos-de-Possibilidades-2011.pdf

35. Reis E. Aprendizagem e docência digital. In: Nobre IA, Nunes VB, Gava TBS, Fávero RP, Bazet LMB, orgs. Informática na educação: um caminho de possibilidades e desafios. Serra: Instituto Federal de Educação, Ciência e Tecnologia do Espírito Santo; 2011. p 67-84. Available from: http://educimat.ifes.edu.br/images/stories/ Publica\%C3\%A7\%C3\%B5es/Livros/Livro-PIE-Caminhos-dePossibilidades-2011.pdf

36. Marin HF. Iniciativa TIGER: Reforma Educacional Orientada pela Tecnologia da Informação. J Health Inform [Internet]. $2017 \mathrm{Jul} / \mathrm{Sep}$ [cited 2019 Apr 11]; 9(3):1-2. Available from: http://www.jhi-sbis.saude. ws/ojs-jhi/index.php/jhi-sbis/article/view/599

37. Hebda T, Calderone TL. What nurse educators need to know about the TIGER initiative. Nurse Educ [Internet]. 2010 Mar/Apr; [cited 2019 Apr 11]; 35(2):56-60. Available from: https://www.ncbi.nlm.nih.gov/ pubmed/20173588

38. Santos CM, Bulgarelli PT, Frichembrider K, Colvara BC, Hugo FN Avaliação da qualidade de aprendizagem no ambiente virtual (Moodle) em saúde bucal, na perspectiva dos discentes. Rev ABENO [Internet] 2018; [cited 2018 Dec 25]; 18(1):116-23. Available from: https://doi. org/10.30979/rev.abeno.v18i1.433

39. Kohan N, Arabshahi KS, Mojtahedzadeh R, Abbaszadeh A, Rakhshan T, Emami A. Self- directed learning barriers in a virtual environment: a qualitative study. J Adv Ave Educ Prof [Internet]. 2017 Jul; [cited 2018 Apr 11];5(3):116-23. Available from: https://www.ncbi.nlm.nih.gov/pmc/ articles/PMC5522903/

40. Tomazini EAS, Tobase L, Teodoro SV, Peres HHC, Almeida DM, Alaverce DC. Online course on advanced life support in cardiorespiratory arrest: innovation for continuing education. Rev Rene [Internet]. 2018; [cited 2018 Dec 25]; 19:e32444. Available from: http:// dx.doi.org/10.15253/2175-6783.20181932444 